\title{
A Proposed Heutagogy Framework for Structural Steel Design in Civil Engineering Curriculum
}

\author{
https://doi.org/10.3991/ijet.v14i24.12091
}

\author{
Shahrin Mohammad $\left.{ }^{(}\right)$, Tan Cher Siang, Sharifah Osman, \\ Nurdiana Yasmin Jamaluddin, Nur Afiqah Mohamed Alfu \\ Universiti Teknologi Malaysia, Kuala Lampur, Malaysia \\ shahrin@utm.my \\ Lee Yeong Huei \\ Curtin University Malaysia, Sarawak, Malaysia
}

\begin{abstract}
Education has traditionally been seen as a pedagogic (child) or andragogic (adult) relationship between the teacher and the learner. Moving parallel with today's technology, learning should also involve in self-exposure to the knowledge by heutagogical method. In this era, information is getting easier to be accessed and shared through online or mobile system. Heutagogy learning is another method for life-long and self-determined learning. As steel is one of the common constructional materials, design information and specifications with the current code of practice should be given to the public in order to obtain reliable and safe buildings. Therefore, this research emphasized the development of heutagogy framework for Eurocode structural steel design in civil engineering curriculum through the collection of information of successful curriculum on heutagogical approach, identification of the learning requirements from learner and educator via questionnaire survey and development of the heutagogy framework with structural equation modelling (SEM) analysis. Data were collected from 315 respondents consisted of learners and educators. The proposed framework focuses on four aspects of heutagogical approach to teaching and learning from different lenses of educators and learners, namely learning plan, design course guidelines, challenge, and assessment. The framework may provide a useful guideline for future heutagogy education through an openaccess platform for the civil engineering curriculum.
\end{abstract}

Keywords-Education, civil engineering, heutagogical approach, structural equation modelling

\section{$1 \quad$ Introduction}

Previously, the methods of andragogy and pedagogy are significant learning approaches towards the education world. Andragogy is the method of teaching adult learners while pedagogy refers to the method of teaching children. The combination of andragogy and pedagogy defines the word heutagogy as well, as it is a self-learning 
method for everyone. The heutagogy is well defined for an individual to learn without a facilitator's supervision.

Learning and teaching that embedded in traditional pedagogy learning models are failed to catch up with current technologies [1-2]. Learning now is still a teachercentred event in a classroom that limited learners' creativity and innovation. Through some literatures, these features of creativity and innovation need to be unlocked by enhancing communication and collaborative skills [3-4], providing authentic learning contexts and tasks [5-8], promoting active learner participation [1,9-10], and perpetuating pedagogies that are learner-centred with technology [11]. Alternatively, turning the learning method from pedagogy to heutagogy may induce innovation.

This paper explores the constructs of heutagogy as being a potentially highly congruent framework for structural steel design in civil engineering curriculum. The possible challenge for educators and educational administrators in considering heutagogy as a potential learning theory is to relinquish some attempts to control and manage learning experiences, and instead empower the self-directive adult learner to accumulate learning experiences within dynamic and unpredictable clinical environments.

\section{$2 \quad$ Literature Review}

Heutagogy refers to self-determined learning. In detail, heutagogy is learnercentric, and future-focused, and the core principle of the approach is for the learner to acquire life-long learning skills in preparation for an uncertain world [12]. This learning method emphasises high learner autonomy, and on the facilitation of a learning environment to build capability and capacity. It also advocates active learner engagement with authentic contexts for creating new knowledge [13-14].

Heutagogy is an approach that engages the theory of complexity when the individual learn through any random responses. The word 'Heut' from ancient Greek explains the individual itself. Heutagogy is clearly a fledgling term that summarizes self-determined learning. Learning occurs through personal experience with the leaner being central to the process. Ideally, heutagogy is best explained in both complexity theory and individual capability on the self-learning approach. Hase and Kenyon [15], originally devised the conceptual framework of heutagogy, see capability as the utilisation of self-efficacy competence to respond to complexity theory [16].

Heutagogy is relatively a new learning and teaching framework [17]. The concept of heutagogy is a student-centered learning and teaching strategies where the learning is directed and determined by the learner. During 2000, heutagogy was abstract as a teaching framework as the web was still in its infancy. These central tenets of heutagogy provide guidelines for design that could be used in a range of learning contexts, including more traditional face-to-face and blended approaches.

The heutagogical approach comprises [17]:

1. An open or flexible curriculum that recognizes the fluid nature of learning.

2. The learner as the driver in determining his/her learning path, context, activities, and journey not just the teacher. 
3. The learner is involved in the design of the assessment or ensures flexibility for the learner to be able to apply it within his/her context.

4. Learning is collaborative.

5. Coaching and scaffolds are provided to the learner when needed.

6. Learner directed questions; this provides an opportunity for true collaboration between the teacher and the learner with regard to the content and process. The questions also provide clarity on what guidance, scaffold, and support are needed by the learner.

7. The learner creates contextually relevant content according to his/her knowledge and learning needs.

8. Encourage reflective practice for deep learning through: learning journals; experiential learning or action research within real-world context; and formative and summative assessment with the view of 'assessment for learning' to provoke thinking and reflection.

Seven significant heutagogical attributes were identified in students learning [18]: self-motivation; desire; self-efficacy; introspection on approaches; strategies and actions; introspection on critical thinking, exploration, and experimentation; introspection on values, beliefs, and assumptions; and capability development.

Heutagogical learning approach outlines the issues that relate to the learners having the openness to be able to negotiate the curriculum, enabling the learner to be able to create contextually relevant content, enabling first-century collaboration between the students and the student and teacher with regards to content and the process, and creating opportunities for situated and serendipitous learning [19-21].

Heutagogy has been successfully implemented and evaluated in multiple undergraduate courses: a vocational foundation degree [22]; landscape architecture, product design, contemporary music, performing and screen arts, and architecture [23]. However, it is yet to be implemented in the civil engineering curriculum.

\section{$3 \quad$ Methodology}

This study employed quantitative research with a descriptive research design. The following subsections discuss the research procedure, research participants and instrument.

\subsection{Overview of research procedure}

Identifying research scopes, problem statement, and detailed critical review on literature: Collect published information on the learning method in the education system. Differentiate between pedagogy, andragogy and heutagogy approaches in the learning process. Highlight the strength of heutagogy learning.

Identifying the successful curriculum (past and on-going) on heutagogy approach and the nature of the civil engineering curriculum: Study on the framework of those successful heutagogical courses and identify their similarities. Investi- 
gate the nature of civil engineering courses such as program outcome, effective method on design course delivery, assessment method, medium of delivery, and others. Adapt a course of civil engineering, namely structural steel design to current heutagogical framework with remarkable modifications.

Identifying the needs of the heutagogy framework from the perspective of the learner through subjective measurement (questionnaire survey): Identify the targeted student population, at least two universities are chosen in this study for comparison. Prepare and draft a questionnaire according to the summarized framework that adapting the civil engineering curriculum. Send the developed questionnaire to experts for verification. After the amendment, the survey is conducted by distributing the questionnaire to the targeted population

Identifying the needs of the heutagogy framework from the perspective of the educator through subjective measurement (questionnaire survey): Identify the targeted academics population, at least two universities are chosen in this study for comparison. Prepare and draft a questionnaire according to the summarized framework that adapting the civil engineering curriculum. Send the developed questionnaire to experts for verification. After the amendment, the survey is conducted by distributing the questionnaire to the targeted population.

Conducting structural equation modeling (SEM) analysis to develop the heutagogy framework for the structural steel design course: Perform SEM analysis from the collected results of the questionnaire survey. From the analysis, the heutagogy framework of structural steel design is developed. This proposed framework will be used to develop heutagogy learning for the civil engineering curriculum in faculty.

\subsection{Research participants}

The population of interest in this study was civil engineering educators and students from Universiti Teknologi Malaysia (UTM) and Universiti Malaysia Sarawak (UNIMAS). 280 respondents were students while another 35 respondents were educators from both universities. Data were collected using Google Online Form Questionnaires.

\subsection{Research instrument}

The questionnaires were created and distributed using Google Online Form for both learners and educators. The questionnaires consist of 5 sections with 117-item questionnaire pertaining to heutagogy from the perspective of learners and educators. Beginning with Section 1 on Demographic Background, followed by Section 2 on Readiness of Self-Learning, Section 3 about Heutagogy Framework for Design Related Course while Section 4 explained on Design Challenges and last section collected about Assessment. All questions were constructed based on content as needed. The instrument used a 4-type Likert scale response questionnaire which determines 1 as Strongly Disagree, 2 represents Disagree, 3 indicates as Agree and 4 for Strongly Agree. 


\section{$4 \quad$ Results and Discussion}

You Heutagogy is a curriculum approach that offers twenty-first-century learning and teaching congruent with the demands of society. In order to form the framework for heutagogy approach in the design course, the data were analysed using SPSS and SmartPLS. Heutagogy is a self-determined learning approach [19]. The SEM results indicated the latent constructs representing the heutagogical approach in the design course. Heutagogy had a strong predictive relationship to the latent constructs. From the analysis, there are four important aspects to be considered by educators and learners when conducting design course using heutagogical approach, namely Learning plan, Design course guidelines, Challenge and Assessment. Table 1 shows the average means for each aspect and SEM weightage values.

Table 1. Average Mean And Sem Weightage Value

\begin{tabular}{|l|c|c|c|}
\hline \multirow{2}{*}{\multicolumn{1}{c|}{ Important Aspects }} & \multicolumn{2}{c|}{ Average Mean } & \multirow{2}{*}{ SEM weightage value } \\
\cline { 2 - 3 } & Educators & Learners & 0.218 \\
\hline Learning Plan & 3.20 & 3.44 & 0.251 \\
\hline Design course guidelines & 3.52 & 3.34 & 0.111 \\
\hline Challenge & 3.44 & 2.69 & 0.270 \\
\hline Assessment & 2.95 & 3.28 & \\
\hline
\end{tabular}

\subsection{Learning plan}

Among items included in this construct were 'I am keen to let the students learn in a group', 'I am keen to let the students search for information independently', 'I prefer to let the students ask questions in class or contribute to class discussions', 'I prefer to provide opportunities for the students to work with other students on projects during class'. As an educator, it is essential to consider learners' advancement in selflearning by planning a lesson $(\mathrm{f}=0.218)$ that involve the students to work independently. As stated by [24], learners need to be involved in negotiating what and how they learn throughout the design and learning process. In order to improve learners' selflearning, guidance by the educator is also required such as reading online journals or articles and searching online quality research papers for references. Interaction during design class is part of the heutagogical approach. Instead of normal face-to-face interaction class, learners preferred interaction via an electronic medium such as smartphone through a mobile application such as Whatsapp, WeChat, Telegram and also email.

\subsection{Design course guidelines}

To provide the design course guidelines was seconded by both educators and learners. Guide the learners by explaining the course guidelines, goal, objective and constraint. The educators need to clearly explain the process plan that related to design course and let the student explore how to gather information about the project. 
Educators need to ask learners to prepare their alternative design solution before to proceed with preferred design based on appropriate evidence and validate the design. In the meantime, the time frame for a project must be informed to ensure that learners able to document and present their design work in a stipulated time.

As for the structural results for design course guidelines, it showed a strong factor ( $\mathrm{f}=0.251)$ among others in order to produce a good design. To relate with the heutagogical approach in the design course, the educators are required to brief detailed guidelines to learners on the first day of class. The briefing is regarding the design goals, objective, and constraint which are essential in conducting the heutagogical approach. It is important for educators to explain the reasons behind every lesson by providing the instruction that focuses on the context of common tasks rather than memorization. This will help learners in a way to plan and gather information. At the same time, the guidelines could be cognizant of diverse learners' backgrounds and experiences. This is related to heutagogy requirement mentioned by [25] describes heutagogy as empowering education as the students' self-determined studies lead to transformational experiences; this benefits individual learners and ultimately society" (p. 111) explore and discover knowledge without having to depend on others. Hence, learners will able to select a design based on the project requirement and validate the design.

\subsection{Challenge}

From the analysis, it showed that the response from educators and learners are closely related. To meet the requirement of the heutagogical approach, an educator should prepare a task or project that manages to challenge learners' understanding and knowledge through self-learning based on experiences and research. The educators agreed that the design objectives are well aligned with the project needs and therefore to ensure the students follow the design objectives but as for learners, to meet the design objectives are challenging. The learners agreed that design must be satisfying to be eligible for consideration and the learners felt hard to identify the constraints. Even though educators preferred to ask the learners to allocate adequate time for problem formulation in the design process, the learners are still facing difficulties to complete the design in time. Another challenge was the task given by educators is preferably something out of the box and the learners agreed with that as they felt challenged to think something out of the box. Presentation and technical reports required by the educators challenged the learners as they have to prepare and formulate design problems, clarify design ideas and explain to others.

The challenge aspects of $\mathrm{f}=0.111$ from the analysis result indicated that educators need to prepare a good and challenging task for learners. Learners really need to understand the objectives of the design. Most of the responses showed that the learners are challenged with the design course. This is why it is important for the educator to brief clearly about the course outline and state a clear instruction for the design. During this phase, educators need to make sure that the learners understand what they need to achieve and the consequences of the learning experiences. To implement the heutagogical approach, [26] argued that educators need to create "a challenging, 
achievable and worthwhile task by providing participants with as much autonomy as possible, and engendering support based on strong and collaborative relationships" (p. 52). Once the learners and educators have reached agreement on the design for the learning, the learners manage to self-learn by selecting any media, application, or tool to support their learning activities. The most challenging point that educators need to consider is the learners' time planning and management in gathering information for the design. Even though heutagogy is a self-learning approach, educators should be flexible and give motivations to the learners by explaining how thinking shifts as a result of the things they have learned. Educators also should give freedom to the learners to create their own designs with their own way of learning and pace [24]. This can be achieved using a variety of learning activities, such as writing, designing, and drawing.

\subsection{Assessment}

Learners and educators need to work together to negotiate how learning outcomes will be assessed. Evaluation could also include forms of participative (self- and peer) evaluation, allowing learners to learn from each other and through self-reflection [23]. The role of the educator is to guide the learner, providing formative feedback that is personalized according to the learner's needs. As for this study, the analysis showed that both learners and educators were agreed that assessment is needed throughout the design course. The overall mean assessment for the educators is 2.95 compared to learners 3.28. It indicated that learners believe that assessment is required as part of the achievement in a way to test their knowledge and understanding about the course. This is because heutagogy is a learning environment that gives opportunities for learners to explore and reflect on what they have learned and how. Meanwhile, educators should aware that learning in heutagogical approach may create conflict for learners who are not taking responsibility for their learning and task. This is as mentioned by [25] in her writings that, once learners have a taste for self-determined learning, few want to return to the restrictions of a fully structured curriculum. From the result, the highest mean is for the assessment method. Educators agreed that assessment method should be delivered to learners at the beginning or introduction of the course. It was seconded by learners as they are fine to be assessed by educators. Learners agreed with a reference can be made (open-book style) during the timed assessment with the highest mean, which is related to heutagogy on self-learning.

Finally, for the assessment 21 st-century results ( $\mathrm{f}=0.270)$, educators need to consider to prepare the assessment for each topic such as quizzes or games for each chapter to help enhance learners' understanding. Another point was assessment brief, which has been agreed by both educators and learners that assessment is important for them to set and have a goal and know what they need to achieve at the end of the lesson. This assessment is a reflection that provides an opportunity to ascend to higher levels of cognitive activity such as analysis and synthesis, and also helps information moves from short- to long-term memory [27-28]. Next, the timing period is an important thing to be considered. Even though heutagogy is a self-learning approach, the learners must have their own learning plans or guidelines or outlines that they need to 
achieve for every topic. Hence, it is necessary for educators to give the dateline for each assignment or assessment. As agreed by both educators and learners that assessment is needed throughout the design project, so that learners are able to solve problems and reinforce their knowledge by sharing information and experiences, continuously practicing, and experimenting by trial and error..

\section{Conclusion}

This paper describes the heutagogy framework as a guide for educators to conduct heutagogical approach in the design course. It consists of four main aspects that educators need to consider before conducting heutagogy learning, namely learning plan, design course guidelines, challenge, and assessment. Hence, heutagogy is possible to be implemented in the design course to challenge learners' ability in terms of soft skill and cognitive skills. Since it is a self-learning approach, learners are more flexible to create, explore, research and organize their tasks as part of heutagogy requirement. Therefore, these skills and attributes have more to do with leadership and selfmanagement that help learners to experience and adapt themselves to future working environment, and at the same time to meet the 21 st-century demands.

\section{Acknowledgement}

This work was supported by the Research University Grant (Q.J130000.2501.17H $53)$.

\section{$7 \quad$ References}

[1] McLoughlin, C., \& Lee, M. J. W. (2008a). Future learning landscapes: Transforming pedagogy through social software. Innovate Journal of Online Education, 4(5). Retrieved from http://nsuworks.nova.edu/cgi/viewcontent.cgi?article $=1044 \&$ context=innovate

[2] Sharples, M., McAndrew, P., Weller, M., Freguson, R., FitzGerald, E., Hirst, T., et al. (2012). Innovating pedagogy 2012: Open University innovation report 1. Milton Keynes, UK: The Open University.

[3] Bruns, A. (2007). Beyond difference: reconfiguring education for the user-lad age. (Ed.), Proceedings of the ICE 3: Ideas, Cyberspace, Education. Ross Priory, Loch Lomond, Scotland.

[4] Laurillard, D. (2007). Pedagogical forms of mobile learning: Framing research questions. In N. Pachler (Ed.), Mobile learning: Towards a research agenda (Vol. 1, pp. 33-54). London: WLE Centre, IoE. Available from http://eprints.ioe.ac.uk/627/1/Mobile C6 Lauril lard.pdf. https://doi.org/10.3726/978-3-0353-0205-9/2

[5] Herrington, A., Herrington, J., \& Mantei, J. (2009). Design principles for mobile learning. In J. Herrington, A. Herrington, J. Mantei, I. Olney \& B. Ferry (Eds.), New technologies, new pedagogies: Mobile learning in higher education (pp. 129-138). Wollongong: UOW. Retrieved from: http://ro.uow.edu.au/newtech/. https://doi.org/10.11645/4.1.1478 
[6] Herrington, J., Herrington, A., \& Olney, I. (2012). Mobile learning in higher education: Authentic tasks, assessment and Web 2.0. In T. Amiel \& B. Wilson (Ed.), Proceedings of the World Conference on Educational Multimedia, Hypermedia and Telecommunications 2012. Retrieved from http://www.editlib.org/p/41020

[7] Herrington, J., Reeves, T. C., \& Oliver, R. (2010). A guide to authentic e-learning. New York: Routledge.

[8] Luckin, R., Clarke, W., Garnett, F., Whitworth, A., Akass, J., Cook, J., et al. (2011). Learner-generated contexts. In M. J. W. Lee \& C. McLoughlin (Eds.), Web 2.0-based elearning: Applying social informatics for tertiary teaching. New York: Information Science Reference. https://doi.org/10.4018/9781605662947.ch004

[9] McLoughlin, C., \& Lee, M. J. W. (2008b). The three Ps of pedagogy for the networked society: Personalisation, participation and productivity. International Journal of Teaching and Learning in Higher Education, 20(1), 10-17.

[10] McLoughlin, C., \& Lee, M. J. W. (2010). Personalised and self-regulated learning in the Web 2.0 era: International exemplars of innovative pedagogy using social software. AJET, 26(1), 28-43. https://doi.org/10.14742/ajet.1100

[11] Siemens, G. (2005). Connectivism: A learning theory for the digital age. International Journal of Instructional Technology and Distance Learning, 2(1), 3-10.

[12] Hase, S., \& Kenyon, C. (2000). From andragogy to heutagogy. ultiBASE, 5(3). Retrieved from $\mathrm{http} / / /$ ultibase.rmit.edu.au/Articles/dec00/hase2.html

[13] Hase, S., \& Kenyon, C. (2003). Heutagogy and developing capable people and capable workplaces: strategies for dealing with complexity. (Ed.), Proceedings of the The Changing Face of Work and Learning Conference. Retrieved from http://epubs.scu.edu.au/cgi/ viewcontent.cgi? article $=1123 \&$ context $=$ gcm pubs

[14] Blaschke, L. M. (2012). Heutagogy and lifelong learning: A review of heutagogical practice and self-determined learning. The International Review of Research in Open and Distance Learning (IRRODL), 13(1), 56-71. Retrieved from http://www.irrodl.org/index.php/ irrodl/article/view/1076. https://doi.org/10.19173/irrodl.v13i5.1424

[15] Hase, S. (2011). Learner defined curriculum: Heutagogy and action learning in vocational training. Southern Institute of Technology Journal of Applied Research, Special Edition: Action research and action learning in vocational education and training. Retrieved from http://sitjar.sit.ac.nz/SITJAR/Special. https://doi.org/10.5040/9781472553232.ch-004

[16] Bhoyrub, J., Hurley, J., Neilson, G. R., Ramsay, M. and Smith, M. (2010) 'Nurse Education in Practice Heutagogy: An alternative practice based learning approach', Nurse Education in Practice. Elsevier Ltd, 10(6), pp. 322-326. https://doi.org/10.1016/j.nepr.2010.05. $\underline{001}$

[17] Narayan, V. and Herrington, J. (2012) 'Towards a theoretical mobile heutagogy framework'.

[18] Gudimetla, C. R. (2017) 'A Study of Fashion Design Students and Faculty Members Perceptions on Self-Determined Learning: Are you ready?', (October)

[19] Hase, S. (2009). Heutagogy and elearning in the workplace: Some challenges and opportunities. Impact: Journal of Applied Research in Workplace E-learning, 1(1), 43-52.

[20] Hou, T. B., \& Hase, S. (2004). Role of action research in workplace PhD research. ALAR Journal, 9(1), 81-92.

[21] Kenyon, C., \& Hase, S. (2010). Androgogy and heutagogy in postgraduate work. In T. Kerry (Ed.), Meeting the challenges of change in postgraduate education. London: Continuum Press. 
[22] Canning, N. (2012). Playing with heutagogy: Exploring strategies to empower mature learners in higher education. Journal of Further and Higher Education, 34(1), 59-71. https://doi.org/10.1080/03098770903477102

[23] Cochrane, T., \& Bateman, R. (2010). Smartphones give you wings: Pedagogical affordances of mobile Web 2.0. Australasian Journal of Educational Technology, 26(1), 114. https://doi.org/10.14742/ajet.1098

[24] Hase, S. (2013). Learner defined learning. In S. Hase \& C.Kenyon (Eds.), Selfdeterminedlearning: Heutagogy in action. . London, UK: Bloomsbury Academic.

[25] Brandt. (2013). The learner's perspective. In S. Hase \& C.Kenyon (Eds.), Selfdeterminedlearning: Heutagogy in action. London, United Kingdom: Bloomsbury Academic.

[26] Dick, B. (2013). Crafting learner-centred processes using action research and action learning. In S.Hase \& C. Kenyon (Eds.), Self-determined learning: Heutagogy in action.United Kingdom. https://doi.org/10.5040/9781472553232.ch-004

[27] Lisa Marie Blaschke, J. E. (2011). Establishing a foundation for reflective practice: A case study of learning journal use. European Journal of Open, Distance, and E-Learning., URL: http://www.eurodl.org/index.php? $\mathrm{p}=$ special $\& \mathrm{sp}=$ articles\&inum $=3 \&$ article $=446 \&$ article $=4$ $\underline{38}$.

[28] Blaschke, L. M. (2012). Heutagogy and lifelong learning:A review of heutagogical practice and self-determined learning. The International Review of Research in Open and Distributed Learning, 56-71.

\section{Authors}

Dr. Shahrin Mohammad is a Professor of Civil Engineering, School of Civil Engineering, Faculty of Engineering, Universiti Teknologi Malaysia. shahrin@utm.my.

Dr. Tan Cher Siang is an Associate Professor of Civil Engineering, School of Civil Engineering, Faculty of Engineering, Universiti Teknologi Malaysia.

Dr. Sharifah Osman is a Senior Lecturer in Education, School of Education, Faculty of Social Sciences and Humanities, Universiti Teknologi Malaysia

Dr. Lee Yeong Huei is a Senior Lecturer in Civil Engineering, Department of Civil \& Construction Engineering, Curtin University, Malaysia

Nurdiana Yasmin Jamaluddin and Nur Afiqah Mohamed Alfu are Postgraduate in Education, School of Education, Faculty of Social Sciences and Humanities, Universiti Teknologi Malaysia.

Article submitted 2019-09-28. Resubmitted 2019-10-27. Final acceptance 2019-11-01. Final version published as submitted by the authors. 